\title{
Biodiversity of Gavurdag Wildlife Development Area
}

\author{
Kerim Güney, Ömer Küçük*, Emre Aktürk, Özkan Evcin
}

Kastamonu University, Faculty of Forestry, Kastamonu, TURKEY.

\begin{abstract}
Natural resources are depleting due to detrimental effects of human interventations. The preservation and rehablitation of these areas are critical. It is very important to identify existing floristic and faunistic elements of these sites for management and future studies. The main purpose of these strategies is to protect and develop the target species and other resource values of the protected area. Besides this, it is also aimed to protect the floristic and faunistic value of the conservation area, in other words protecting the biodiversity. It is aimed to investigate and document the floristic and faunistic values in Gavurdag Wildlife Development Area in this study. According to floristic results, 618 plant taxa were found and 97 of them were detected as endemic in the study field (Endemism ratio: $15.7 \%$ ). Moreover, when the IUCN categories are examined; 7 species are found to be in En category and 10 species are found to be in the Vu category. In addition, 15 mammal and 64 bird species were detected with faunal research in the field.
\end{abstract}

Key words: Biodiversity, Flora, Fauna, Wildlife, Gavurdag.

\section{INTRODUCTION}

Natural resources are depleting due to detrimental effects of human interventations. The preservation and rehablitation of these areas are critical. Governments and non-governmental organizations have been developing rules, regulations and startegies in order to protect natural resources. ${ }^{11}$ The Nature Conservation Status Report prepared by the Ministry of Forestry and Water Affairs of the Republic of Turkey shows the activities carried out in the country during $2002-13$ for the protection of natural areas. According to this report, while the number of protected areas in Turkey nationwide in 2002 was 964 in 2002, that has been increased to 3049 in 2013. In addition, there is also a hundred percent increase in the area totals of the total protected fields in Turkey. ${ }^{23}$ One can be clearly seen that from this report, the need for the conservation of natural areas will increase over time.

In order to protect natural areas in the country, eighty regions were identified under the category of wildlife development areas since $2003 .{ }^{21}$ Wildlife development areas are special fields where wildlife ecosystem of the region have complete legal protection. The main purpose of these strategies is to protect and develop the target species and other resource values of the protected area. Besides this, it is also aimed to protect the floristic and faunistic value of the conservation area, in other words protecting the biodiversity. ${ }^{9-16}$

Biodiversity was defined by Duraiappah as 'Biodiversity is the variability among living organisms from all sources, including terrestrial, marine, and other aquatic ecosystems and the ecological complexes of which they are part; this includes diversity within species, between species, and of ecosystems. ${ }^{6}$ Importance and protection of biodiversity have been well studied by scientists. The protection of biodiversity in our country is important for many industries such as forestry, agriculture, pharmacology and tourism but also has a great importance for natural, ecological and human health. ${ }^{1-17-19-22}$
DOI: 10.5530/ijper.51.3s.49 Correspondence: Ömer Küçük, Kastamonu University, Faculty of Forestry, Kastamonu, TURKEY 37150 Phone no: +905425803858 Email Id: omerkucuk@kastamonu.edu.tr 
Results of changing all elements of biodiversity such as genetic and population diversity can be catastrophic for the future of our world. ${ }^{2-24}$ Therefore, it is very important to identify existing floral and faunal elements for management and future studies. Kastamonu province is in a position to enclose the elements of the Euro-SIberian phyto-geographical region, with its rich diversity in terms of flora and fauna. The province hosts 1780 plant species, 255 of them are endemic. Therefore, 40 mammal species, and 129 bird species exist in this city. ${ }^{18}$ Gavurdag Wildlife Development Area is also rich in biodiversity like Kastamonu. Due to the reasons stated above, the Gavurdag Wildlife Development Area was deemed suitable for this study. The primary focus of the study was aimed to investigate and document the floristic and faunistic values in Gavurdag Wildlife Development Area. The strategies were developed by using the current state of biodiversity indicators to help the future protection plans. Current status and potential threats to the species have been identified with the the help of former studies. $^{3-25}$

\section{MATERIALS AND METHODS Study Area}

Gavurdag1 Wildlife Development Area is in Kastamonu province and within the boundaries of the Tosya district. It is $10 \mathrm{~km}$ far from the town of Tosya and $77 \mathrm{~km}$ far from the city of Kastamonu. The total area of this region is 9261.6 ha and the altitude ranges from 1040 to $2380 \mathrm{~m}$. (Karatas Hill). The topography of the study area is very rugged and steep. It has a very sloping and faulted structure terrain and the average slope is about $50-60 \%$. Plain open areas are small and usually located in high-altitude hills. In addition, there is no forest village or neighborhood in this area. The climate is characterized as transition zone between West Black Sea Region and Central Anatolia Region. Summers are cool, winters are harsh, and the precipitation is in the form of rain and snow. According to the climatic data obtained from Kastamonu central station, the average annual temperature is $10.9^{\circ} \mathrm{C}$ during the past 38 years (1975-2014). Moreover, the average monthly rainfall in Kastamonu is 35.1 millimeters. ${ }^{20}$ In addition, the identification of ecosystem types of the study area has been mapped because it is important to determine the existence of plant and animal populations.

\section{METHODS}

The study is based on direct observations i.e. data collection from the field. Braun- Blanquet Minimal Sample
Area sampling method were applied to data and results were mapped by using GIS software for floral studies. Sample area sizes were determined according to 'Aims and methods of vegetation ecology' book. ${ }^{7}$

In order to determine mammal species, the results of the interviews with the local people and the findings on the land were evaluated. Observations and inspections were carried out on water edges, passages, forest edges and mixed-leaved forests. Observations (follow-up, faecal examination) were usually made on foot. Habitat areas were determined taking into consideration of the wild animals circulation areas, feeding areas, feeding time, water resources, and places of settlement. In addition, habitat areas were shown as dots on the map.

In order to detect the bird species of the wildlife development area and nearby areas, interviews with the local people were carried out by studying the land and considering the bird species that can be found according to the habitat characteristics. The conservation status of the species has been prepared using the current International Union for Conservation of Nature (IUCN), Bern Convention and Convention on International Trade in Endangered Species of Wild Fauna and Flora (CITES) lists. ${ }^{3-14}$

\section{RESULTS}

\section{Flora of Gavurdag Wildlife Development Area}

According to the results of the research, within Kastamonu Tosya Gavurdag Wildlife Developmet Area, 23 taxa in the form of tree in the region, 27 taxa in the form of shrub and ivy, and 568 herbaceous form were determined. A total of 97 taxa within 618 taxa found are endemic in this area. The endemism ratio was found $15.7 \%$. A summary of the IUCN categories of plant species in the study area is shown (Table 1). Taxa in Endangered (En) category are; Delphinium ilgazense, Potentilla umbrosa subsp. decrescens, Cirsium pubigerum var. paphlagonicum, Asyneuma rigidum subsp. graminifolium, Scrophularia serratifolia, Blysmus compressus, and Festuca ilgazensis. Taxa in Vulnerable (Vu) category are; Spiraea crenata, Arabis abietina, Erysimum smyrnium, Silene paphlagonica, Tripleurospermum rosellum var. album, Asyneuma ilgazensis, Asperula cymulosa, Asperula capitellata, Listera cordata, and Festuca riganensis. In addition to them, Vaccinium arctostaphylos and Cyclamen coum are protected by Bern Convention and Dactylorbiza nieschalkiorum, Dactylorbiza osmanica var. osmanica, and Cephalanthera rubra are protected by CITES. Due to the categories of the species mentioned above, it has been determined that there is a protection priority over other species. 
Table 1: The IUCN Categories of plant taxa within the study area

\begin{tabular}{|c|c|}
\hline IUCN Categories & Total Number of Plant Taxa \\
\hline En & 7 \\
\hline Vu & 10 \\
\hline NT & 12 \\
\hline LC & 54 \\
\hline CD & 12 \\
\hline DD & 3 \\
\hline
\end{tabular}

\section{Fauna of Gavurdag Wildlife Development Area}

\section{Mammals}

Fifteen mammal species were determined in the Gavurdag Wildlife Development Area and the obvervations were based on September-December period. Ten of these species are defined as LC (Least concern), and one categorized as DD (Data deficient) in IUCN Red List. Moreover, the IUCN category of Spermophilus xanthoprymnus, a species identified in the field, is defined as NT (Near threatened) which means to become endangered in the near future most likely.

\section{Birds}

These data were obtained from field observations and examinations made during the migration period (October). Sixty four bird species have been identified in Gavurdag Wildlife Development Area and near vicinity. Although the vast majority of these species are in the category of LC, Gypaetus barbatus are in NT according to IUCN Red List.

\section{Target Species-Red Deer (Cervus elaphus)}

The studies carried out in the Gavurdag Wildlife Development Area of Kastamonu province Tosya district were found to have a suitable habitat characteristic for the Red Deer, which is one of the important mammal species, and it was found that this species are naturally found in this area.

\section{DISCUSSION AND CONCLUSSION}

Kastamonu Tosya Gavurdag Wildlife Development Area has an imperative value for wildlife and biodiversity along with its important water resources, mixed forests with natural bore, leafy and leafy, especially flora. However, this may not be resonable to say that the richness in wildlife is very prominent in terms of mammal species. On the other, this field is rich in bird species and plant species. There are no natural resource values that are naturally deteriorated or damaged for any reason. This means that protectection of this area has been successful up to now. However, some precautions must be taken to ensure that the resource values in the area are protected in the future. In order to protect the biodiversity and sustainable utilization of the natural resources, the threats and pressures on these resource values must be determined first and then the strategies and activities for eliminating them are required. According to the current status of the Gavurdag Wildlife Development Area, it was determined that the protection of the Red Deer must be primary conservation target. In addition, protection of natural forests and in-forest water resources, which contain rich plant and animal species, is the primary safeguard to maintain and increase the red deer population.

\section{ACKNOWLEDGEMENT}

We wish to thank Dr. Irfan Ashraf because of his advices and efforts in this article.

\section{CONFLICT OF INTEREST}

None

\section{ABBREVIATIONS USED}

IUCN: International Union for Conservation of Nature; CITES: Convention on International Trade in Endangered Species of Wild Fauna and Flora; En: Endangered; Vu: Vulnerable; NT: Near Threatened; LC: Least Concern; CD: Conservation Dependent; DD: Data Deficiency; GIS: Geographic Information Systems.

\section{REFERENCES}

1. Ajazuddin SS. Legal regulations of complementary and alternative medicines in different countries. Pharmacognosy reviews. 2012;6(12):154.

2. Chapin lii FS, Zavaleta ES, Eviner VT, Naylor RL, Vitousek PM, Reynolds HL, Hooper DU, Lavorel S, Sala OE, Hobbie SE, Mack MC. Consequences of changing biodiversity. Nature. 2000;405(6783):234-42.

3. Cites [database on the Internet]. Convention on International Trade in Endangered Species of Wild Fauna and Flora - [cited 2017 May 10]. Available from: https://cites.org/

4. Council of Europe [database on the Internet]. Convention on the Conservation of European Wildlife and Natural Habitats - [cited 2017, May 10]. Available from: http://www.coe.int/en/web/conventions/full-list/-/conventions/treaty/104

5. Davis P. Flora of Turkey and the East Aegean islands 1-9. Edinburgh, etc. 1965.

6. Duraiappah A, Naeem S, Agardi T, Ash N, Cooper D, Díaz S, et al. Ecosystems and human well-being: biodiversity synthesis. World Resources Institute, Washington, DC. 2005;86.

7. Ellenberg D, Mueller-Dombois D. Aims and methods of vegetation ecology. New York, NY: Wiley; 1974.

8. Ekim T, Koyuncu M, Vural M, Duman H, Aytaç Z, Adigüzel N. Türkiye bitkileri kirmizi kitabi. Ankara: Türkiye Tabiatini Koruma Dernegi \& Yüzüncü Yil University. 2000.

9. Evcin Ö, Küçük Ö, Akkuzu E, Ugış A. Habitat preferences of roe deer (Capreolus capreolus) in Kastamonu: case study of Elekdağı wildlife 
development area. International Journal of Engineering Sciences \& Research Technology 2017;6(4):225-29 .

10. Flora Araştırmaları Derneği [database on the Internet] Bizim Bitkiler - [cited 2017 Feb 10]. Available from: http://www.bizimbitkiler.org.tr/v2/index.php

11. Guloglu Y. National and international conservation of biological diversity in terms of administrative law "sample of Turkey". InGenetic Diversity 2017. InTech.

12. Güner A, Aslan S, Ekim T, Vural M, Babaç MT. Türkiye Bitkileri Listesi (Damarı Bitkiler). Nezahat Gökyiğit Botanik Bahçesi ve Flora Araştırmaları Derneği Yayını. İstanbul. 2012:47-83.

13. Güner A, Özhatay N, Ekim T, Başer KH. Flora of Turkey and the east Aegean islands, Vol. 11. Second Supplement, Edinburgh. 2000.

14. International Union for Conservation of Nature [database on the Internet]. IUCN Protected Areas Categories - [cited 2017 Feb 4]. Available from: https:// www.iucn.org/theme/protected-areas/about/protected-areas-categories

15. Hoekou YP, Tchacondo T, Karou SD, Koudouvo K, Atakpama W, Pissang P, Gbogbo AK, Woegan AY, Batawila K, Akpagana K, Gbeassor M. Ethnobotanical study of latex plants in the maritime Region of Togo. Pharmacognosy research. 2016 Apr;8(2):128.

16. Huang HP, Wang J, Huang LQ, Gao SL, Huang P, Wang DL. Germplasm preservation in vitro of Polygonum multiflorum Thunb. Pharmacognosy magazine. $2014 \mathrm{Apr} ; 10(38): 179$.

17. Jain S, Dwivedi J, Jain PK, Satpathy S, Patra A. Medicinal Plants for Treatment of Cancer: A Brief Review. Pharmacognosy Journal. 2016;8(2).
18. Kastamonu Valiliği Çevre ve Şehircilik İ Müdürlüğü [database on the Internet]. Kastamonu İli 2014 Yılı Çevre Durum Raporu - [cited 2017 Mar 4]. Available from: http://www.csb.gov.tr/db/ced/editordosya/Kastamonu\%20 2014.pdf

19. Kaya Z, Raynal DJ. Biodiversity and conservation of Turkish forests. Biological Conservation. 2001;28;97(2):131-41.

20. Orman ve Su İşleri Bakanlığı Meteoroloji Genel Müdürlüğü [database on the Internet]. TÜMAS - [cited 2017 Mar 4] Available from: http://tumas.mgm.gov. tr/wps/portal/

21. Özer M. Yaban hayatı geliştirme sahaları ve bunların yönetimi ve geliştirme planları hakkında [monograph on the Internet]. TMMOB Orman Mühendisleri Odası Mesleki Teknik Geliştirme Eğitimi Ders Notları; 2012 [cited 2017 Mar 11]. Available from: http://ormuh.org.tr/arsiv/files/OMO\%20Yaban $\% 20$ Hayati\%20Gel\%20Sah.pdf

22. Petrovska BB. Historical review of medicinal plants' usage. Pharmacognosy reviews. 2012;1;6(11):1.

23. Republic of Turkey Ministry of Foresty and Water Affairs General Directorate of Nature Conservation and National Parks [database on the Internet]. Status Report on Nature (2002-203) - [cited 2017 Jan 11]. Available from: http:// www.milliparklar.gov.tr/kitap/100/?sflang=tr (accessed 11.01.2017).

24. Sala OE, Chapin FS, Armesto JJ, Berlow E, Bloomfield J, Dirzo R, HuberSanwald E, Huenneke LF, Jackson RB, Kinzig A, Leemans R. Global biodiversity scenarios for the year 2100. Science. 2000;10;287(5459):1770-4.

25. Tubives [database on the Internet]. Turkish Plants Data Service - [cited 2017 May 10] Available from: http://www.tubives.com/

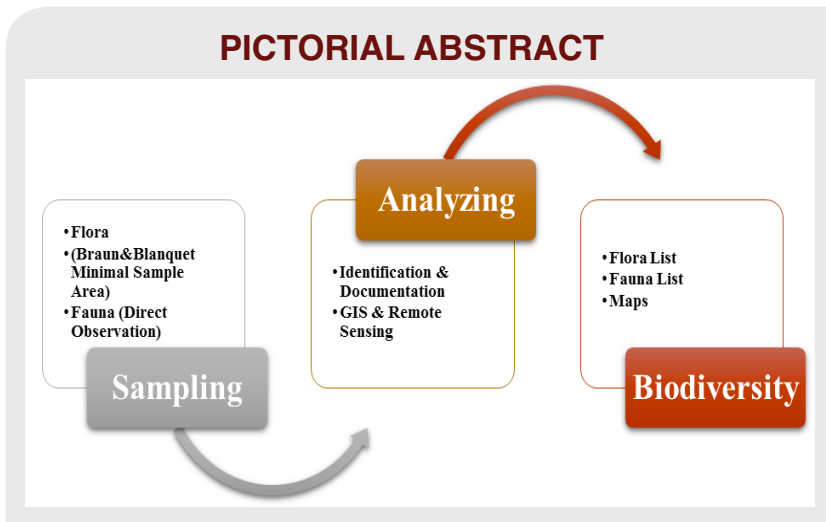

\section{ABOUT AUTHORS}

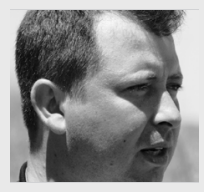

Dr. Kerim Güney: He has been working as Assistant Professor at Botanic department, Forest Engineering Faculty in Kastamonu University. Kerim Güney has many publications on flora, vegetation, biodiversity and medical and aromatic plants.

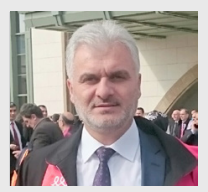

Dr. Ömer Küçük: Professor at Kastamonu University, Dean of Forestry Faculty. He received his MSc and PhD from Karadeniz Technical University, Turkey. He is focused on forest fire management and wildlife management. He has many international publications, also he is a member of editorial boards on many international journals. He is guiding many MSc and PhD students.

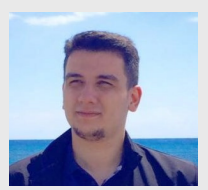

Emre Aktürk: Research Assistant at Kastamonu University, Faculty of Forestry. He received his MSc from Clemson University, South Carolina, USA. He is working about GIS, remote sensing and vegetation ecology. 
Özkan Evcin: PhD Candidate, Research Assistant at Kastamonu University, Faculty of Forestry. He received his MSc from Kastamonu University, Turkey. He is focused on wildlife ecology and management. He has many national and international publications.

Cite this article: Güney K, Küçük Ö, Aktürk E, Evcin Ö. Biodiversity of Gavurdag Wildlife Development Area. Indian $\mathrm{J}$ of Pharmaceutical Education and Research. 2017;51(3)Suppl:S368-72. 